\title{
Ecological Engineering - a View on Tasks and Challenges
}

\author{
Joanna Kostecka'
}

1 Department of Biological Foundations of Agriculture and Environmental Education, Faculty of Biology and Agriculture, University of Rzeszów, M. Ćwiklińskiej 1A, 25-601 Rzeszów

e-mail: jkosteck@ur.edu.pl

"The world does not need more successful people anymore.

Planet Earth desperately needs more people of peace, healers, restorers, storytellers and lovers of all kinds, needs people to live well, needs people with moral courage to make the effort to create a more humane and friendly world for its inhabitants, and these values have little to do with the success in the sense in which it is defined by modern civilization. "

$\sim$ David W. Orr, writer, ecologist activist, scientist, academic professor

\begin{abstract}
The following elaboration presents a view on the tasks and challenges which should be faced by ecological engineering in the near future. The study also emphasizes the need to disseminate the concept of retarding the pace of transformation of ecosystems and natural resources as well as proper understanding and urgent implementation of strategically correct provisions from the existing legal acts. It also refers to the need to look for the effective methods of disseminating the activities for the protection of ecosystems, in which accepting the concept of "violence on the environment" may be helpful. The ecological engineering activity may be divided into: a) activities in natural areas, including rural ones, to protect and restore their ecosystem services, b) activities in increasingly biologically poorer urbanized and industrialized areas in order to create the conditions for the well-being of residents, in the reality of climate change and the prevention of further rapid change in the region, intensified by anthropogenic pressure, c) involvement in education. In the background of this division, the necessary activities of the active PTIE members include: 1) Discussing, analyzing and pointing out the problems of protection and rational use of the environment as well as natural and anthropogenic resources, 2) Organizing multidisciplinary scientific and educational conferences, 3) Development, publication and dissemination of knowledge in the field of counteracting the environmental degradation as well as the ways of protecting and rationalizing the use of the environment, 4) Cooperation with various organizations (including administration) in solving the ecological and economic problems, 5) Participation in the process of ecological legislation, 6) Opinions, eco-engineering and counseling for local communities.
\end{abstract}

Keywords: ecological engineering, PTIE, tasks, challenges, retardation, violence on the environment

\section{INTRODUCTION}

Achieving sustainable development by combining the economic growth with environmental protection requirements and participation in building a civil society is a serious challenge for all citizens of the world, including people of different professions.

The ecological and biodiversity protection issues are currently on the path of free technological and economic development. In the last 200 years, the man has devastated a huge part of the natural environment. The Earth's technosphere now weighs over 30 billion tons, which is more than 50 kilograms for every square metre of the Earth's surface. The number of humancreated "technofossils" that will remain on Earth for a long time and will testify to the impact of the "anthropocene" civilization is higher than the number of species of organisms evolving in nature for millions of years (Zalasiewicz et al., 2016; Zalasiewicz and Williams, 2017). Therefore, it seems that the work for the creation of solutions which reduce the human pressure on 
the environment concerns primarily those who perform technical professions. The current situation is forcing people to radically change their approach to nature if their civilization is to survive. The UN Environment's sixth Global Environment Outlook (GEO) (2019) calls us to take immediate action to address the pressing environmental issues to achieve the Sustainable Development Goals. By bringing together a community of hundreds of scientists, peer reviewers and collaborating institutions and partners, the GEO reports build on sound scientific knowledge to provide governments, local authorities, businesses and individual citizens with the information needed to guide societies to a truly sustainable world by 2050 .

People have to revise the erroneous anthropocentric vision of the place of the man on Earth and replace it with an ecocentric perspective, in which the man occupies an unspecified position among other elements of nature. Such views are accepted and represented by more and more groups of people (including the youngest protesters under the Parliaments of various countries of the world (Greta Thunberg, 2019)), demanding that their votes be taken seriously by politicians, ruling parties and the rest of society. It is worth noting that in the last years of the 20th century, the understanding of "ecological threat" has expanded and has been replaced by "environmental threat" and thus the threat of the entire anthroposphere - natural, social, cultural and spiritual environment of both the individual and the entire human population.

Among the threats of the anthroposphere, apart from natural, one should mention many created and intensified by the man himself: greenhouse effect, acid rainfall, ozone hole, eutrophication of water resources, deforestation of the globe, environmental pollution including hazardous waste, nuclear explosions, lowfood production quality and much more. All the above-mentioned manifestations of degradation pertaining to the natural and social environment also, directly or indirectly, cause the tragic disappearance of the richness of the Earth's biological diversity, i.e. plants, animals and fungi. Thus, the circle of risk growth closes because it results in the disappearance of ecosystem services, proper functioning of which is the basis of life on Earth, also for the man.

On the basis of an international venture - Millennium Ecosystem Assessment (2005) - at the beginning of the 21 st century, it was known that $60 \%$ of services were destroyed or used in a way that did not ensure their durability. In the 1970s, for the first time, humanity had consumed more resources over the year than the Earth can recreate. In order to begin a public discussion of this problem, in 1987, the British think tank New Economic Foundation set up an Ecological Debt Day (EDD). Then, it took place on October 23rd and since then a little earlier every year has been. In 2019, the World EDD will probably be in August, but it also counts for individual countries and regions, for the European Union - according to the WHO report and the Global Footprint Network it is on 10th May. For most of the year, we live on a loan that will pay future generations (Country Overshoot Days; EU Overshoot Day).

Many authors emphasize the importance of the ecosystem services for humans, animals and other representatives of the natural environment (Millennium Ecosystem Assessment, 2005; Fisher et al., 2009; De Groot et al., 2010; GEO, 2019). "Ecosystem services" is a set of benefits that the environment provides to society and the economy. Recognition of mutual dependencies and mechanisms between individual ecosystem services is very important, because it can improve the ability of service recipients to better manage the natural resources, landscapes or stand to preserve the biodiversity of ecosystems (CavenderBares et al., 2015). Among the global processes for which it is necessary to set boundaries for safe human activities on the Earth, these limits have already been exceeded in terms of climate change threatening the human safety, undermining the nitrogen cycle and the rate of biodiversity loss (Rockström et al., 2009).

Counteracting this last phenomenon is one of the main goals of contemporary authorities in the field of nature conservation. Extreme opinion is represented here by Edward O. Wilson (2016) postulating the allocation of as much as half of the Earth to strict nature reserves, which could help recreating numerous ecosystems and save the biodiversity contained in them also with a view to the man. However, this would not only slow down the degradation of ecosystems but also limit the economic development in the current sense. We are now in danger of a catastrophe, which requires a change of perspective from a short-term to a long-term survival strategy.

The justification for preserving the natural resources in a non-deteriorated condition, and 
ultimately increasing their durability and quality, would therefore have to be understood and accepted by corporations, entrepreneurs, all employee groups, policy-makers and the average citizen of all ages. Meanwhile, the care for natural resources, for example in nature-rich areas (landscape parks, protected landscape areas or Natura 2000) is still not understood and seen as a barrier to development (Kostecka, 2019), while the preservation of ecosystem services is a necessary condition for improving the broadly understood quality of human life.

The following study presents a view on the tasks and challenges which should be faced by ecological engineering in the 21 st century. The study also emphasizes the need to disseminate the concept of retarding the pace of natural resources transformation as well as proper understanding and urgent implementation of strategically correct provisions from existing legal acts. It also refers to the need to look for effective methods of disseminating activities for the protection of ecosystems, in which accepting the concept of "violence on the environment" may be helpful.

\section{ECOLOGICAL ENGINEERING AND ITS TASKS}

According to Siuta (2010), ecological engineering is the theoretical and applied knowledge of many scientific and technical disciplines, constituting the basis for rational use and protection of the natural environment as well as natural and anthropogenic resources.

In order to complement this legitimate claim, however, it is worth to refer to the fact that ecological engineering should be primarily based on promoting a change in the way of thinking; from the consumer to rational use of the resources mentioned above.

It serves the ecological development of civilization. Ecological engineering protects the natural resources, adapts and creates the conditions necessary for human, plant and animal life. It should be emphasized that the modern world, full of conflict situations in the field of socioenvironmental-economic issues, needs the people with knowledge and abilities, fast learners, open and critical skills. An adult citizen taking part in shaping the world in accordance with the requirements of ecological engineering, should not only have extensive technical knowledge directly in the field of his profession, but also allow a holistic view of the situation in which he works, lives or relaxes. It should also enable to provoke participation in the broadly understood social life, because the need to involve citizens in the organization and functioning of systems that limit the human pressure on the environment is one of the general social problems of the present day. Many authors claim that the education in the basics of environmental protection and ecological engineering should be included in the syllabuses of all education programmes. It is a fact that every economic and living activity of people causes both the desired and undesirable changes in the natural environment. These changes may be direct or indirect, anticipated or unexpected, reversible and irreversible. In the design of technologies, facilities and systems, in the implementation of investments and in the use of technical equipment, geological resources and ecological structure, as well as any other activity, an engineer is the main perpetrator of direct and indirect ecological consequences. She/he must be aware of this and feel responsible for the effects that accompany her/his activities. Only a coherent and consistent system of education from primary school to higher education can help bear such a responsibility. Shaping the intellectual elite of the country, this system should be based on strong and broad foundations, returning to the ethos of truth and the moral shaping of the human-human and human-nature relations. This can not be achieved quickly and here it is worth promoting the concept of retarding the pace of life in favour of its quality ${ }^{1}$.

Siuta [2010] states that currently, there are no known ecological harmless ways of using the environment and natural resources. However, an

\footnotetext{
${ }^{1}$ Confrontation with this concept is facilitated by regular scientific conferences entitled "Retardation of material transformation of resources. Achievements, problems, perspectives", organized at the University of Rzeszów. The first took place on 14-15th. 09. 2009 (materials of 14 presentations were published in the Bulletin of The Committee for the National Land Development, Polish Academy of Sciences, 2010, no 242. 220 pp.), the second took place at 1011. 09. 2012 (materials of 22 papers and posters were published in the Ecological Engineering. 2013. no 34.228 pp.). The third of the conferences took place on 15-17. 09. 2016 (gathered participants presenting 38 topics published mainly in the Polish Journal for Sustainable Development, 2016, vol. 20190 pp. and also in 2017 in Ecological Engineering and Journal of Ecological Engineering)
} 
engineer, while designing this use, has great possibilities to minimize the adverse consequences of the human presence in ecosystems, by choosing such solutions that will entail the least negative effects of space exploitation and locating facilities.

The use of appropriate technologies and production systems, ecological protection in all phases of construction and use of facilities or a specific area, reclamation of a degraded environment and creation of new ecological values gives a chance to slow down the unfavorable trends. Those who, in accordance with the Constitution of the Republic of Poland (1997), actively participate in creating sustainable development should be deeply convinced of the need to create innovative works of technology slowing down the further transformation of ecosystems or the consumption of resources.

Pro-environmental engineering has also been defined, for example, by Robert Constanza and William Mitsch. These authors define ecological engineering as designing the ecosystems that integrate the human society with the natural environment for the benefit of both components (Constanza, 2012; Mitsch, 2012). According to these authors, ecological engineering has been developing over the past 30 years, but especially rapidly in recent years. Its goals now include the restoration of the ecosystems that have been significantly disrupted by the human activities and the development of new ones that have both human and ecological values. This is especially necessary because the resources of conventional energy sources are decreasing and the strengthening of ecosystem services of nature is needed more and more, according to well-prepared legal acts (Kostecka, 2017).

In the context of the information above, it therefore seems reasonable to introduce the concept of potentially renewable resources into common knowledge and common understanding, stressing that only at the appropriate pace (slowing down their exploitation) they have a chance to continue to serve human beings.

Constanza (2012) and Mitsch (2012) emphasized that there are several university centers in the world dealing with the programmes or activities in the field of ecological engineering. This is indicated by the growing number of publications submitted both in the journal Ecological Engineering (Elsevier) and in the Polish Journal of Ecological Engineering. Currently, many companies which specialize in the renewal of natural runs of watercourses, cleaning lakes, restoration of forests, grasslands and wetlands, rehabilitation of post-mining and post-industrial areas and creation of wetlands or phytoremediation are developing. It seems that the synchronization of the work of universities, publishing houses, research resources and practice determines the development of the field and begins to bring the desired results (Mitsch, 2012).

Is this how it is in Poland? It seems that this growing knowledge and activity are still too often faced with social resistance when it comes to introducing the solutions developed by ecological engineering into life.

Too often, the average citizen does not understand either the need to care for ecosystem services, or is she/he ready to limit the race for material goods or take creative efforts to protect the environment (Kostecka, 2013; 2019).

\section{SHOULD ECOLOGICAL ENGINEERING ASSIMILATE AND PROMOTE THE CONCEPT OF RETARDING THE ECOSYSTEMS TRANSFORMATION AND THE CONCEPT OF "VIOLENCE ON THE NATURAL ENVIRONMENT"?}

As any field of knowledge and activities, ecological engineering should adapt to the needs of the environment. In view of the growing ecological debt of the whole globe, the need to urgently slow down the transformation of ecosystems and the loss of biodiversity is essential. This issue should therefore be disseminated. According to, for example, Poskrobko and Kostecka (2016), the term retardation (slowing down) may be used. It is a concept useful in creating the new philosophy of management, because management is a social process. In the recent period of industrialization, humanity has focused mainly on production, consumption and maximizing profits. The anthropogenic burden of the natural environment was raised and management models were simplified. The concept of the retarding the pace of natural resources transformation is against the still-accepted fact that industry under the influence of marketing 1.0 (Fuciu and Dumitrescu 2018) developed since the mid-twentieth century, provides consumers with more and more unnecessary goods, also in the form of unnecessary packaging, multilingual instructions and other additions that are useless and quickly reach 
landfills or wild rubbish dumps. The justification for a reasonable management of resources has been present in European law as well as in Polish law for a long time (Kostecka 2017).

The actions of all citizens are important for slowing down the transformation of ecosystems (retardation). As a consequence, it will help to slow down the consumption of non-renewable resources and will lead to the preservation of potentially renewable natural resources in an undegraded condition, and ultimately even increase their durability and quality. As mentioned above, it must be widely understood and accepted; it is also necessary to use the methods of self-education.

The adoption of new perspectives is one of the cognitive skills during the development of civilization. As ever, we need flexible engineers with interactive minds involved in the search for solutions for the survival strategy in the destroyed nature. The concept of "violence on the natural environment" (Butt and Kostecka 2019, Kostecka and Butt 2019) has a chance to mobilize the people's conscience to reflect on the current development, and this can be a source of new beliefs about what we should do. It seems that the introduction of the term "violence on the natural environment" as one of the foundations of ethical issues will deepen the perception of the world by people in dire need of changing the perspective of perceiving the relationship with nature.

In Figure 1 it has been suggested that technology may not be a strategically sufficient engine of the economy at present. Involvement in educational activities, both through the sources of formal and informal education, must also make environmental engineers aware of the complexity of knowledge and ecological culture of society as very important elements of the infrastructure that determines the economic development, protection and rational use of the environment, as well as shaping the need to replace anthropocentric philosophy with an ecocentric perspective. Only this belief gives an opportunity for a safe and long-term use of the $40 \%$ of global ecosystem services remaining for humanity and for renewing the environment in accordance with the tasks of broadly understood ecological engineering.

\section{SELECTED FACTS FROM THE HISTORY OF POLISH SOCIETY OF ECOLOGICAL ENGINEERING}

The Polish Society of Ecological Engineering (PTIE) was established in 1990 and obtained legal personality in the same year. It is a continuation of the Polish Committee for Environmental Design and Protection (established in 1972) as part of the structures of the Supreme Technical Organization (currently the Federation of Scientific and Technical Associations). The main purpose of establishing PTIE was to take the measures to adapt the economic development to the requirements of shaping and protecting the natural environment. The PTIE's statutory goals are implemented through expert, publication and educational activities. The main activity of PTIE focuses on popularizing the rational use and

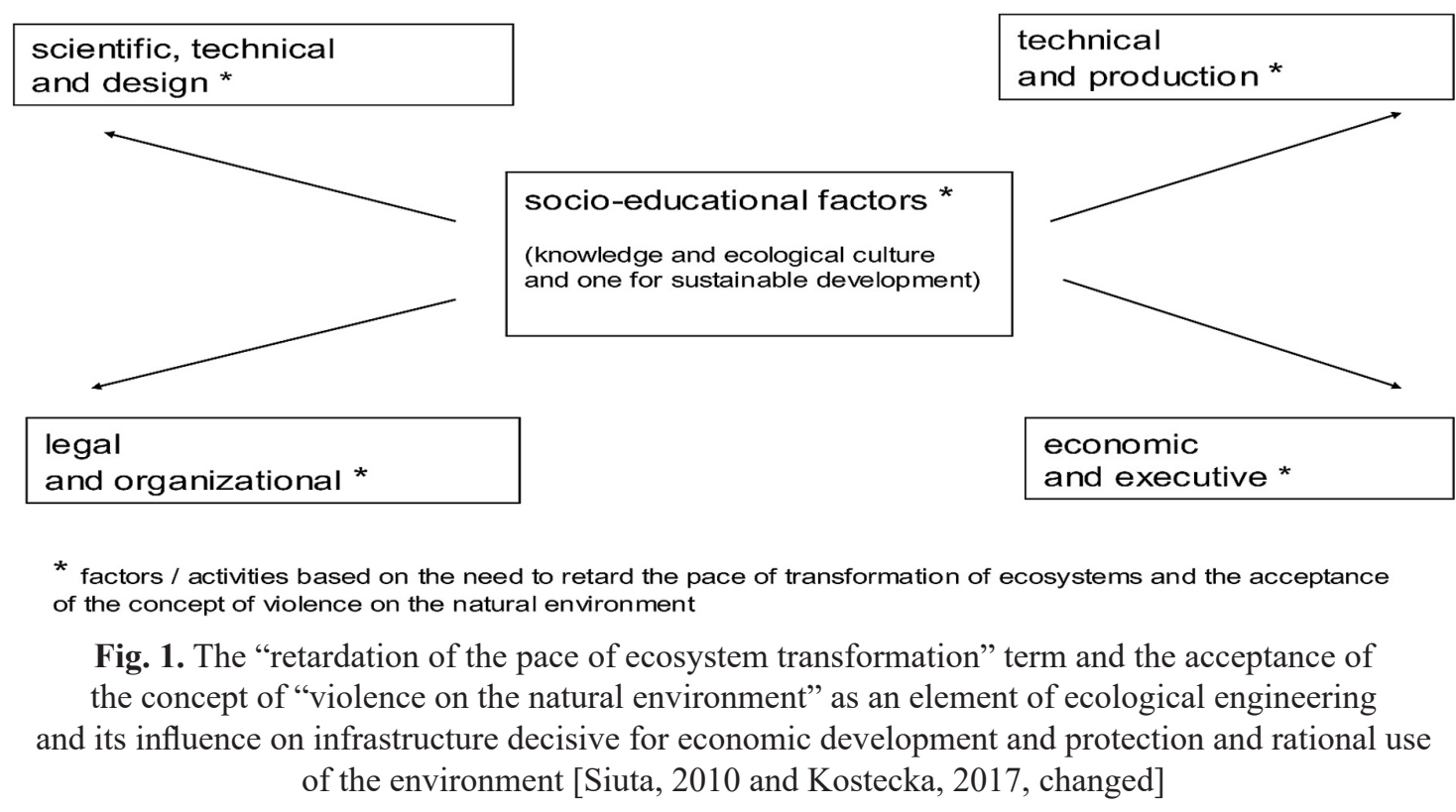


protection of the natural environment and natural resources of the Earth. Currently, with rapid scientific and technical progress, dynamic economic development, and over-exploitation of natural resources, ecological engineering is inherent in the environmental policy of Poland and the world, contributing to sustainable development. The activities of Society members should protect, adapt and create the conditions necessary for human, plant and animal life. The Society strengthens its position in the world of science by publishing scientific magazines in Polish and English (,Journal of Ecological Enginering" - in English language, "Inżynieria Ekologiczna" - in Polish language, "Polish Journal for Sustainable Development" - in both languages and "Zeszyty Naukowe. Inżynieria Ladowa $i$ Wodna $w$ Ksztaltowaniu Środowiska"). PTIE cooperates with various scientific and research centers as well as with enterprises in addition to the local and state administration in solving local economic and ecological problems. More detailed data on the tasks, history of the creation and operation of PTIE and the most important achievements of the Society can be found in the studies of Siuta $(1999 ; 2002$; 2010) and Kiryluk (2015).

In 2019, PTIE was awarded a banner. Its reverse was provided with the sentence "We protect and renew the natural environment", hoping that it will merge the existing members and new ones will encourage to actively build the further history of the Society.

\section{CHALLENGES FOR POLISH SOCIETY OF ECOLOGICAL ENGINEERING}

The members of the Society face very serious tasks and even challenges related to the civic cocreation of sustainable development in the human functioning in the 21 st century. They could be divided into two main areas:

- ecological engineering activities in still very valuable natural areas, including rural areas, to protect and restore their ecosystem services;

- ecological engineering activities in increasingly biologically poorer urbanized and industrialized areas. These serve to create the conditions for the well-being of residents, in the reality of climate change and the prevention of further rapid change in the region, intensified by the anthropogenic pressure.
Both mentioned engineering activity paths should be supported by a broadly conducted, also as part of the PTIE activities, educational activity for the purpose of modifying the way of thinking about the rate of biodiversity and ecosystem resources utilization. All new engineering ideas must prevent the unreasonable and unsustainable exploitation of living organisms, air, water, soil, mineral resources and, above all, space, as well as eliminate all unnecessary economic and social changes of the environment aimed at its degradation. They should also focus on cleaning up these resources from waste. The most important ideas are the technologies of effective collection and recycling of plastics and other wastes from the seas and oceans, management of water resources, energy acquisition, municipal and industrial waste management, solutions for tourism of a devastating environment and a spatial economy that is sparing the Earth. The ecological education and education for sustainable development, conducted by the PTIE members, should disseminate the broadly understood pro-environmental behaviors and solutions to the problems of the hotel industry, tourism, transport, methods of production and consumption of food, housing and others. However, these issues must be assimilated both by humanists and the people with technical education as well as disseminated in all age groups.

As already mentioned, the technical and technological solutions should be accompanied by proper (economical and thoughtful) space management. It should be based on a long-term law. Spatial development plans and issuing permits have to be consulted and approved by the experts who understand the functioning of ecosystems (e.g. members of PTIE, Institute for Environmental Protection - National Research Institute, Institute for Sustainable Development, Nature Conservation League, Polish Chamber of Ecology, Naturalists' Clubs). Although the industrial activity has long been limited by law, the engineer must accept current solutions and seek new ones to reduce the harmfulness of the anthropogenic pressure to air, water, soil and biodiversity. The challenges in improving the human-nature environment relations in the areas of agriculture production are equally important.

Talking about being eco-friendly is easy. The urgent introduction of theory into practice is much more important. We cannot afford to waste time. It is important to talk about being environment-friendly, but first and foremost, we 
have to show how to do it (e.g. practically during the organization of projects and conferences promoting the ecological issues that must respect the pro-environmental principles). The attention of ecological engineers should be paid to the pro-environmental technological standards and their solutions should constantly neutralize such threats as pollution with low emissions and automotive emissions, electromagnetic fields, elimination of problematic substances, care for non-renewable and potentially renewable resources, and rules for access to them. They must pay attention to improve the best available technologies for using water of good quality (owing to adequate models of river basin; retention and anti-flood measures) (Kostecka 2013; 2017; Kostecka et al., 2013; Leniart, 2015).

In accordance with the principle of saving resources, one must give up or at least gradually reduce the burning of everything with the justification of this fact for energy production (Bukowski, 2017). Renewable energy sources should be understood and used with caution, appreciating the saving and use of recyclable materials in purposes other than obtaining energy. This also applies to the biodegradable waste, important both due to their water and ecological footprint during food production, as well as nutritional and environmentally-friendly needs for biodegradable waste. It is possible to cope without the additional energy from biomass. However, fertile soil and good-quality yields are indispensable. All pro-environmental innovations are also extremely important, in addition to reliable information and its understanding by all decision-makers and organs of the social organization of the state. Therefore, there are not only good knowledge and experience, but also communicative skills, interpersonal skills and team work among the requirements currently posed to eco-engineers. Resilience to stress, honesty, commitment, conscientiousness, loyalty and credibility are also valuable.

\section{CONCLUSIONS}

A systematic analysis of the available literature, quality audits and current legal documents will allow identification of the main barriers to shaping the pro-environmental behaviors and technologies. The industrial revolution drew from an unlimited environment, ecological engineering has a chance based on the ongoing IT revolution to help create the solutions for organizing a life that satisfies people and limits the negative impact on the ecosystem services. We need to better understand the rules of using the potentially renewable resources and give them time to regenerate according to the forces of nature. Ecological engineering should therefore promote retarding the pace of ecosystem transformation, also strengthening respect for nature by accepting the concept of violence on the natural environment.

The members of PTIE should actively cooperate in new partnerships, confidently consult and substantively coordinate activities in line with the achievements of environmental education. It is worth noting that despite the progress, the state of this education currently conducted and the saturation of eco-actions, information, materials and good knowledge are insufficient. What is needed, therefore, is the participation of the PTIE members in locked-in and substantively prepared, long-lasting activities with the participation of the press, radio and television. One should not be afraid of stigmatizing the incorrect actions of other residents (neighboring threats). We have only one Earth and we borrowed it from our grandchildren. Nature does not need people, but people do need nature. If we do not stop the destruction of ecosystems, nothing will matter anymore.

Summing up the importance of presented problems, it can be argued that necessary activities of active members of PTIE include:

1. Discussing, analyzing and pointing out the problems of protection and rational use of the environment as well as the natural and anthropogenic resources,

2. Organizing multidisciplinary scientific and educational conferences,

3. Development, publication and dissemination of knowledge in the field of counteracting the environmental degradation as well as the ways of protecting and rationalizing the use of the environment,

4. Cooperation with various organizations (including administration) in solving the ecological and economic problems,

5. Participation in the process of ecological legislation,

6. Opinions, eco-engineering and counseling for local communities. 


\section{REFERENCES}

1. Butt KR., Kostecka J. 2019. Opinions of English students on the term "Ecological violence". PJfSD. 23(1). DOI: 10.15584/pjsd.2019.23.1.1.

2. Bukowski Z. 2017. Activities of the European Union at the turn of 2016 and 2017 concerning the circular economy, including in the field of waste management. Waste management (in Polish). PZIiTS, Poznań.

3. Cavender-Bares J., Balvanera P., King E., Polasky S. 2015. Ecosystem service trade-offs across global contexts and scales. Ecology and Society, 20(1), 22.

4. Country Overshoot Days. https://www.overshootday.org/newsroom/country-overshoot-days/.

5. Costanza R. 2012. Ecosystem health and ecological engineering. Ecological Engineering, 45, 24-29.

6. De Groot R.S., Alkemade R., Braat L., Hein L., Willemen L. 2010. Challenges in integrating the concept of ecosystem services and values in landscape planning, management and decision making. Ecological Complexity.7(3), 260-272.

7. EU Overshoot Day. Living Beyond Nature's Limits. 10 may 2019. WWF-World Wide Fund For Nature, Brussels, Belgium. 1-19. https://www.footprintnetwork.org/ content/uploads/2019/05/WWF_GFN_ EU_Overshoot_Day_report.pdf.

8. Fisher B., Turner R.K., Morling P. 2009. Defining and classifying ecosystem services. Ecological Economics. 63, 643-653.

9. Fuciu M., Dumitrescu L. 2018. From Marketing 1.0 To Marketing 4.0 - The Evolution of the Marketing Concept in the Context of the 21ST Century. International conference Knowledge-Based Organization. 24(2), DOI: 10.1515/kbo-2018-0064.

10. GEO. Global Environment Outlook. Healthy Planet, Healthy People. 2019. UNEP. https://www.un.org/ en/climatechange/reports.shtml.

11. Greta Thunberg: The Swedish teen inspiring climate strikes. BBC News. 14 Feb 2019. https:/www.bbc. com/news/av/world-europe-47231271/greta-thunberg-the-swedish-teen-inspiring-climate-strikes.

12. Kiryluk A. 2015. Dwadzieścia pięć lat Polskiego Towarzystwa Inżynierii Ekologicznej. Inż. Ekolog. 44, 1-11. DOI: https://doi.org/10.12912/23920629/ 60017.

13. Konstytucja RP z 2 kwietnia 1997 r. Dz.U. 1997 nr 78 poz. 483 .

14. Kostecka J. 2013. Self evaluation on the way to retardation of pace of life and resources transformation. Problems of Sustainable Development. 8, (2), 93-102.

15. Kostecka J. 2017. References to the concept of retardation of transforming natural resources into selected legal acts in the context of building sustainable development and a circular economy (in Polish). Inżynieria Ekologiczna, 6, 1-15. https://doi. org/10.12912/23920629/79430.
16. Kostecka J. 2019. Are you going to change your everyday habits to protect ecosystems? Unpublished data.

17. Kostecka J., Butt K.R. 2019. Violence on the natural environment. Problemy Ekorozwoju - Problems of Sustainable Development, 14(2), 183-189.

18. Kostecka J., Pączka G., Piękoś P. 2013. Environmental rules for the organization of conferences (in Polish). Inżynieria i Ochrona Środowiska, 16(4), 499-510.

19. Lenart W. Wyzwania edukacji ekologicznej w przededniu naboru konkursowego NFOŚiGW w 2015 roku. Uniwersytet Warszawski. https://www.google. $\mathrm{com} / \mathrm{url}$ ? sa $=\mathrm{t} \& \mathrm{rct}=\mathrm{j} \& \mathrm{q}=\&$ esrc $=$ s\&source $=$ web $\& \mathrm{~cd}$ =1\&ved $=2$ ahUKEwjPkabW86DjAhVMKFAKHb doB9IQFjAAegQIARAC\&url=https $\% 3 \mathrm{~A} \% 2 \mathrm{~F} \% 2 \mathrm{~F}$ www.nfosigw.gov.pl $\% 2 \mathrm{Fdownload} \% 2 \mathrm{Fgfx} \% 2 \mathrm{Fnfo}$ sigw $\% 2 \mathrm{Fpl} \% 2 \mathrm{Fnfoaktualnosci} \% 2 \mathrm{~F} 868 \% 2 \mathrm{~F} 266 \% 2$ F2\%2Fwyzwania_edukacji_ekologicznej.pdf\&usg $=\mathrm{AOvVaw} 2 \mathrm{AB} 7 \mathrm{rwtsG} 8 \mathrm{fu} 8 \mathrm{WDin} 7 \mathrm{vpRN}$.

20. Mitsch W.J. 2012. What is ecological engineering? Ecological Engineering. Vol. 45, 5-12. http:/www.sciencedirect.com/science/article/pii/ S0925857412001310.

21. Millenium Ecosystem Assessment 2005. Ecosystems and Human Well-being, Island Press, Washington, DC.

22. Poskrobko B., Kostecka J. 2016. Retardation in social awareness (in Polish). Pol. J. Sust. Dev.. 20, 145-160. DOI: 10.15584/pjsd.2016.20.16.

23. Rockström J., Steffen W., Noone K., Person A., Chapin S.F., Lamin E.F., Lenton T.M., Scheffer M., Folke C., Schellnhuber H.J., Nykvist B., de Wit C.A., Hughes T., van der Leeuw S., Rodhe H., Sörlin S., Synder P.K., Costanza R., Svedin U., Falkenmark M., Karlberg L., Corelli R.W., Fabry V.J., Hansen J., Walker B., Liverman D., Richardson K., Crutzen P., Foley J.A. 2009. A safe operating space for humanity. Nature, 461, 472-475.

24. Siuta J. 1999. Ecological Engineering and Polish Society for Ecological Engineering. (in Polish). Chemia i Inżynieria Ekologiczna, 10, 961-967.

25. Siuta J. 2002. Ecological engineering in my business (in Polish). Wyd. Nauk. G. Borowski, Warszawa.

26. Siuta J. 2010. Twenty years of the Polish Society for Ecological Engineering (PTIE) (in Polish). Inżynieria Ekologiczna, 22, 114-119.

27. Wilson E.O. 2016. Half-Earth: Our Planet's Fight for Live. Liveright Publishing Corporation. New York-London.

28. Zalasiewicz J., Williams M. Waters C.N. 2016. Scale and diversity of the physical technosphere: A geological perspective. The Anthropocene Review. DOI: $10.1177 / 2053019616677743$.

29. Zalasiewicz J., Williams M. 2017. The Earth's technosphere shows how humans are permanently reshaping our planet. https://soundcloud.com/ university-of-leicester. 